\title{
Age influence on quality of shell and penetration in bacterial laying lightweight eggs
}

\author{
[Influência da idade na qualidade da casca e na penetração bacteriana em ovos de poedeiras leves] \\ B.D. Smaniotto ${ }^{1}$, A.F. Amarante ${ }^{2}$, R. Altarugio ${ }^{1}$, I.G.O. Silva ${ }^{1}$, I.M.O.Corrêa ${ }^{1}$, L.Q. Pereira ${ }^{3}$, \\ M.M.P. Sartori ${ }^{4}$, R.L. Andreatti Filho ${ }^{4}$, P.T.C. Guimarães-Okamoto ${ }^{4}$, A.S.Okamoto ${ }^{4 *}$ \\ ${ }^{1}$ Aluno de pós-graduação - Universidade Estadual Paulista - Unesp - Botucatu, SP \\ ${ }^{2}$ Aluno de graduação - Universidade Estadual Paulista - Unesp - Botucatu, SP \\ ${ }^{3}$ Instituto Federal de Educação - Tefé, AM \\ ${ }^{4}$ Universidade Estadual Paulista - Unesp - Botucatu, SP
}

\begin{abstract}
This study evaluated the influence of the bird's age on the quality of the shell and percentage of bacterial penetration in commercial eggs. White-shelled commercial eggs were used, laid by light laying hens in their first laying cycle at 21, 39, 51, and 62 weeks of age. Shell quality evaluations comprised: egg weight, specific gravity, percentage and thickness of shell, number and size of pores. For evaluations regarding bacterial penetration, strains of several enterobacterias and one salmonella were used, all of which resistant to Nalidixic acid $(100 \mu \mathrm{g} / \mathrm{ml})$. The method employed for evaluation of bacterial penetration was filling the eggs with growth medium. The data were subjected to variance analysis with $5 \%$ of probability using SAS (Education Analytical Software, 2013). Eveb though increase in the laying hen's age caused reduction of the quality of eggshells, it failed to affect the percentage of penetration of the bacterial samples evaluated.
\end{abstract}

Keywords: poultry, bacterial contamination, eggs, enterobacteria

\section{RESUMO}

O presente estudo avaliou a influência da idade da ave sobre a qualidade da casca e na porcentagem de penetração bacteriana em ovos comerciais. Foram utilizados ovos brancos comerciais provenientes de poedeiras leves em primeiro ciclo de postura com 21, 39, 51 e 62 semanas de idade. As avaliações de qualidade da casca realizadas foram: peso do ovo, gravidade específica, porcentagem e espessura da casca, número e tamanho dos poros. Para as avaliações da penetração bacteriana, foram utilizadas cepas de diversas enterobactérias e uma salmonela, sendo todas resistentes ao ácido nalidíxico $(100 \mu \mathrm{g} / \mathrm{mL})$. O método utilizado para a avaliação da penetração bacteriana foi por meio do preenchimento dos ovos com meio de cultura. Os dados foram submetidos à análise de variância com $5 \%$ de probabilidade utilizando-se o programa SAS - Statistical Analisys System (Education Analytical Software, 2013). O aumento da idade da poedeira promoveu a redução da qualidade da casca dos ovos, porém não foi capaz de influenciar a porcentagem de penetração das amostras bacterianas avaliadas.

Palavras-chave: aves, contaminação bacteriana, ovos, enterobactérias

\section{INTRODUCTION}

The eggshell works as natural packaging to internal components by acting as a physical barrier, hampering pathogenic penetration and excessive water loss (Barbosa et al., 2012).

Recebido em 18 de novembro de 2016

Aceito em 9 de janeiro de 2017

*Autor para correspondência (corresponding author)

E-mail: sakai@fmvz.unesp.br
As laying hens grow older, they lay eggs with larger weight and surface, and thinner shells (Raghiante et al., 2010; Swiatkiewicz et al., 2015). In this context, eggs for human consumption with shells of inferior quality are more likely to be contaminated by microorganism, representing a higher risk to consumer health (Carvalho and Fernandes, 2013; Mazzuco and Bertechini, 2014). 
Bacterial contamination of the eggs may occur in two possible ways: vertical, during egg formation in the bird's reproductive tract; or horizontal, through contact of egg with feces, bedding, nest, collector's hands, trays, and contaminated surfaces, the latter being the main mode of pathogen transmission in eggs for human consumption (Mendes et al., 2014).

Since no laws in effect require stores to keep eggs for human consumption refrigerated, they are kept in room temperature from the moment they are laid to the moment they are bought, being, in some cases, refrigerated only at the consumer's house (Xavier et al., 2008). This lack of refrigeration throughout the production chain along with alterations in shell quality elevate the risks of human infection by pathogens that can reach the internal content of the eggs and arrive at the consumer's plate (Pinto and Silva, 2009).

In a study by Pinto and Silva (2009), when evaluating the penetrative capacity of Salmonella Enteritidis in eggs with varying shell qualities and subjected or not to refrigeration, higher levels of penetration of this pathogen in unrefrigerated eggs with defective shells were observed.

Even though bacterial shell penetration through isolation of the internal content of whole eggs has been extensively studied (Sauter and Petersen, 1974; Raghiante et al., 2010; Katayama et al., 2012), research connecting the said evaluation with shell quality through filling the eggs with growth medium are scarce.

This study aims to evaluate the influence of the laying hen's age in eggshell quality and incidence of bacterial penetration through shell pores by filling the eggs with growth medium.

\section{MATERIAL AND METHODS}

The eggs where collected from four lots of commercial white laying hens of lightweight lineage, aged 21, 39, 51, and 62 weeks, from a commercial farm in Botucatu, São Paulo, all on the same day and identified according to the ages of evaluated laying hens, with sampling restricted to those free of dirt, deformities and cracks.
For each of the four evaluated ages, 53 eggs were sampled, identified, and assigned to analyses of specific gravity, egg weight and bacterial penetration; 10 eggs for analyses of pores numbers and sizes; and 8 for the analyses of shell thickness and percentage, amounting to 71 sampled eggs per group and 284 white-shelled eggs in total.

The experiment was carried out from December 2014 to January 2015, at the Laboratory of Avian Pathology of the School of Veterinary Medicine and Animal Science of São Paulo State University, Botucatu - São Paulo. Immediately after collection, the eggs were subjected to ovoscopic evaluation for disposal of those with fissures and cracks, weight determination in precision digital scale and evaluation of specific gravity according to the method proposed by Hamilton (1982), which consists of the flotation of the eggs in saline solutions with increasing density concentrations in $\mathrm{g} / \mathrm{cm}^{3}$ : 1,$060 ; 1.065$; $1.070 ; 1.075 ; 1.080 ; 1.085 ; 1.090 ; 1,095$ and 1,100 followed by washing of the same with distilled water for the removal of residues of saline solution.

For shell percentage evaluations, the eggs were cracked on the equatorial region, had internal contents removed, and, for removal of albumen residues, the shells were washed in running water and laid out to dry in room temperature for 24 hours. After drying, they were placed in a forced ventilation oven, where they remained at $65^{\circ} \mathrm{C}$ for 72 hours. After balance with room temperature, the shells were weighed in digital scale for measuring of shell percentage, obtained by dividing the egg weight values and multiplying the result by 100 .

The same samples evaluated were used for evaluation of shell thickness. Employing a digital caliper type $684132 \mathrm{~F}$, three measurements were made in the equatorial region of the egg, followed by calculation of their means per egg, with the result expressed in millimeters.

Evaluation of bacterial penetration was performed in 53 eggs of each evaluated group, employing the method described by Reu et al. (2006). 
A hole of about one centimeter of width was opened on the basal part of the shell - extremity containing the air chamber - employing electric rotary tool DC-130B-5, internal contents were removed with a vacuum pump type WP6111560, three serial washings of the shells were made with sterile ultrapure water for removal of albumen residue, and shells were left for drying in room temperature for 24 hours in bacterial cultivation storage with ultraviolet light.

The shells were then filled with nutrient agar containing $100 \mu \mathrm{g} / \mathrm{ml}$ of Nalidixic acid (Nal), $0.1 \%$ of $2,3,5$ triphenyltetrazolium hydrochloride (TTC) and $100 \mu \mathrm{g} / \mathrm{ml}$ of itraconazole. After agar solidification, the hole was sealed with sterile commercial silicon.

Ten bacterial samples resistant to $100 \mu \mathrm{g} / \mathrm{ml}$ of Nalidixic acid (Nal) were used for preparation of the inoculum, namely strains of Citrobacter freudii, Enterobacter cloacae, Escherichia coli, Hafnia alveii, Klebsiella pneumonii, Providencia stuartii, Pseudomonas aeruginosa, Serratia marcenses, Shigella spp. and Salmonella Enteritidis, from the bacteria collection of the Laboratory of Avian Pathology of the School of Veterinary Medicine and Animal Science of São Paulo State University, Botucatu - São Paulo.

Itraconazole was used to prevent possible fungi contaminations that might ultimately interfere with results. The TTC added to the medium colored the existing bacteria colonies.

Firstly, each bacterial sample was incubated separately in sterile tubes containing $5 \mathrm{ml}$ of BHI (brain-heart infusion) broth for 24 hours at $37^{\circ} \mathrm{C}$. After incubation, a pool of the bacteria was made through suspension on one milliliter from each sample, which had been diluted 100 times in sterile beaker containing BHI broth.

For bacterial quantification of the inoculum, a sample of $100 \mu \mathrm{g}$ was collected, then subjected to serial dilutions in sterile PBS (phosphatebuffered saline), then incubated in nutrient agar with $100 \mu \mathrm{g} / \mathrm{mL}$ of $\mathrm{Nal}$ at $37^{\circ} \mathrm{C}$ for 24 hours from each dilution.

Each evaluated group was immersed separately in this pool for three minutes, after drying in room temperature, the eggs were placed in sterile commercial egg cartons and then stored for 21 days in room temperature (average of $23.2^{\circ} \mathrm{C}$ ) on previously sanitized room.

Throughout the 21 days, daily samples (three eggs) from each group were collected aseptically, and, one by one, submerged in $70 \%$ ethanol solution in sterile plastic bags for three minutes. After drying in sterile Petri dishes at room temperature, the shell of each group sample was carefully removed and the agar was examined for previous identification of contaminating bacterial colonies. The contents of the three eggs from each group were placed in plastic bags that had been previously sterilized and washed in $10 \mathrm{ml}$ of PBS. This wash was then plated in nutrient agar $\mathrm{Nal} 100 \mu \mathrm{g} / \mathrm{ml}$ and incubated at $37^{\circ} \mathrm{C}$ for 24 hours.

After the incubation period, the presence of morphologically distinct colonies was evaluated in the plaques corresponding to each group/collecting, which were then re-isolated separately with platinum handles in plaques of nutrient agar Nal $100 \mu \mathrm{g} / \mathrm{ml}$ and incubated for 24 hours at $37^{\circ} \mathrm{C}$. Subsequently, the re-isolated strains were identified through incubation in biochemical mediums at $37^{\circ} \mathrm{C}$ for 24 hours (Cowan, 1974).

Eggs assigned to pore numbers and sizes evaluation were inspected employing the recommendations of Tyler (1953).

With a scissor, the shells were separated in three groups of about two centimeters each, namely, the apical, equatorial, and basal portions. In each shell fragment, an area of $1 \mathrm{~cm}^{2}$ and four subareas of $25 \mathrm{~mm}^{2}$ were demarcated. Each group was immersed in $65 \%$ nitric acid solution for 25 seconds to remove the cuticle and membranes from the shell. They were then washed in distilled water and left to dry in room temperature for 3 hours. Each fragment was placed in microscope slides and analyzed with a Zeiss ${ }^{\circledR}$ scanning electron microscope type Lab. A1 Axion in 5X objective and computer program Axion Vision Rel 4.8, with the number of pores $/ \mathrm{cm}^{2}$ for each region were attained by adding the four subareas, and the number of pores through the average of the three portions of the shell. For evaluations of pore sizes and diameter, the same samples and reading equipment previously used were employed. 
The data were subjected to variance analysis with $5 \%$ of probability using SAS (Education Analytical Software, 2013).

The methodology described in this experiment was approved by the Ethics Committee in Animal Experimentation of the School of Veterinary Medicine and Animal Science of São Paulo State University "Júlio de Mesquita Filho",
Botucatu, under protocol number 168/2014CEUA.

\section{RESULTS AND DISCUSSION}

There was a significant difference $(\mathrm{P} \leq 0,05)$ of ages for egg weight (EW), specific gravity (SG), shell percentage (SP) and shell thickness (ST) variables, as shown in Table 1.

Table 1. Egg weight (ew), specific gravity (sg), shell percentage (sp), shell thickness (st) of eggs from laying hens of varying ages

\begin{tabular}{ccccc}
\hline Age & $\begin{array}{c}\text { ew } \\
(\mathrm{g})\end{array}$ & $\begin{array}{c}\mathrm{sg} \\
\left(\mathrm{g} / \mathrm{cm}^{3}\right)\end{array}$ & $\begin{array}{c}\text { sp } \\
(\%)\end{array}$ & $\begin{array}{c}\text { st } \\
(\mathrm{mm})\end{array}$ \\
\hline 21 & $53.30 \mathrm{c}$ & $1.098 \mathrm{a}$ & $10.43 \mathrm{a}$ & $0.53 \mathrm{a}$ \\
39 & $62.46 \mathrm{~b}$ & $1.086 \mathrm{~b}$ & $9.31 \mathrm{~b}$ & $0.49 \mathrm{ab}$ \\
51 & $66.93 \mathrm{a}$ & $1.085 \mathrm{~b}$ & $9.31 \mathrm{~b}$ & $0.47 \mathrm{bc}$ \\
62 & $67.41 \mathrm{a}$ & $1.081 \mathrm{~b}$ & $8.35 \mathrm{c}$ & $0.41 \mathrm{c}$ \\
\hline Average & 62.52 & 1.088 & & 0.47 \\
\hline asd & 0.9855 & 0.0016 & 0.1947 & 0.0163 \\
Probability & 0.0000 & 0.0000 & 0.0000 & 0.0001
\end{tabular}

Averages followed by different lowercase letters in the column differ significantly according to Tukey's Test $(\mathrm{P} \leq 0.05)$. asd - average standard deviation.

Concurring with the literature, the results achieved show that the laying hen's age directly influences the EW. Eggs from laying hens aged 62 and 51 weeks show larger weight than the ones from hens aged 39 and 21 , respectively. This data agrees with findings by Barbosa et al. (2012) and Trindade et al. (2007), which reported larger EWs as the bird aged. According to Almeida et al. (2006), this is due to the production of larger ovarian follicles, which determine the production of eggs with large yolks, thereby increasing the ratio of yolk weight and egg weight.

The values for SG and ST were higher in eggs from younger birds. Souza (2012) observed similar results, with decreasing values as the bird ages.

Moreover, Hamilton (1982) states that these parameters are directly correlated and, therefore, when there is a reduction in the SG, the ST will consequently be reduced as well. According to Lauvers and Ferreira (2011), this is due to lower intestinal absorption capacity and bone calcium mobilization to the shell gland observed in older birds, with their ion retention rate being of $40 \%$ whereas that of younger birds is of $60 \%$.
Age influence $(\mathrm{P} \leq 0.05)$ over $\mathrm{SP}$ was observed, with eggs from younger birds showing higher values for this parameter than the ones from birds aged 62 weeks, corroborating Barbosa et al. (2012). As reported by Valente (2011), as the bird ages, the SP does not increase in the same proportion as the $\mathrm{EW}$, since the amount of calcium mobilized for shell formation, regardless of age progression, remains the same, with only a lower rate of calcium carbonate deposition by area unit and, thereby, a lower SP.

As shown in Table 2, the bird's age influenced significantly $(\mathrm{P} \leq 0.05)$ the number of pores in the shell (NP), with older birds showing higher NP by $\mathrm{cm}^{2}$ than younger ones. Similar data have been found in the studies of Barbosa et al. (2012). Pore size, however, suffered no influence $(\mathrm{P}>0.05)$ from bird's age (Table 3 ).

Regardless of evaluated age, NP averages were higher in the apical than in the basal region. This data corroborates findings by Scala Junior (2003), who affirms that there is higher NP in the apical region than any other region. 
Age influence on quality...

Table 2. Number of pores in the shell by laying hen's age

\begin{tabular}{cccc} 
& \multicolumn{3}{c}{ Number of Pores/cm $\mathbf{c}^{2}$} \\
\cline { 2 - 4 }$($ Age & Apical & Equatorial & Basal \\
\hline 21 & 4.0 & $5.0 \mathrm{~B}$ & $4.0 \mathrm{~B}$ \\
39 & 4.0 & $5.0 \mathrm{~B}$ & $4.0 \mathrm{~B}$ \\
51 & 5.0 & $5.0 \mathrm{~B}$ & $6.0 \mathrm{~A}$ \\
62 & 5.0 & $6.0 \mathrm{~A}$ & $5.0 \mathrm{~A}$ \\
\hline Average & 7.35 & 8.79 & 17.51 \\
\hline Probability & 0.062 & 0.032 & 0.001
\end{tabular}

Averages followed by different uppercase letters in the column differ according to the Kruskal-Wallis Test $(\mathrm{P} \leq 0.05)$.

Table 3. Pore size by egg region and laying hen's age

\begin{tabular}{cccc}
\hline & & $\begin{array}{c}\text { Pore Size } \\
(\mu \mathrm{m})\end{array}$ & \\
$($ Weeks $)$ & Apical & Equatorial & Basal \\
\cline { 2 - 4 } & 23.85 & 23.79 & 20.72 \\
39 & 20.29 & 22.55 & 23.84 \\
51 & 24.71 & 20.34 & 20.96 \\
62 & 20.65 & 18.41 & 19.39 \\
\hline Average & 22.38 & 21.27 & 21.23 \\
\hline asd & 1.6645 & 1.9367 & 2.1793 \\
Probability & 0.1878 & 0.2492 & 0.5436 \\
\hline (P<0,05)- Noteworthy effect according to Tukey's Test. asd
\end{tabular}

$(\mathrm{P} \leq 0,05)$ - Noteworthy effect according to Tukey’s Test. asd - average standard deviation.

When related to ages, higher NP in the equatorial region was observed for the age of 62 weeks. Ages of 51 and 62 weeks showed higher NP for the basal region than other ages, and there was no significant difference in the apical region for any age.
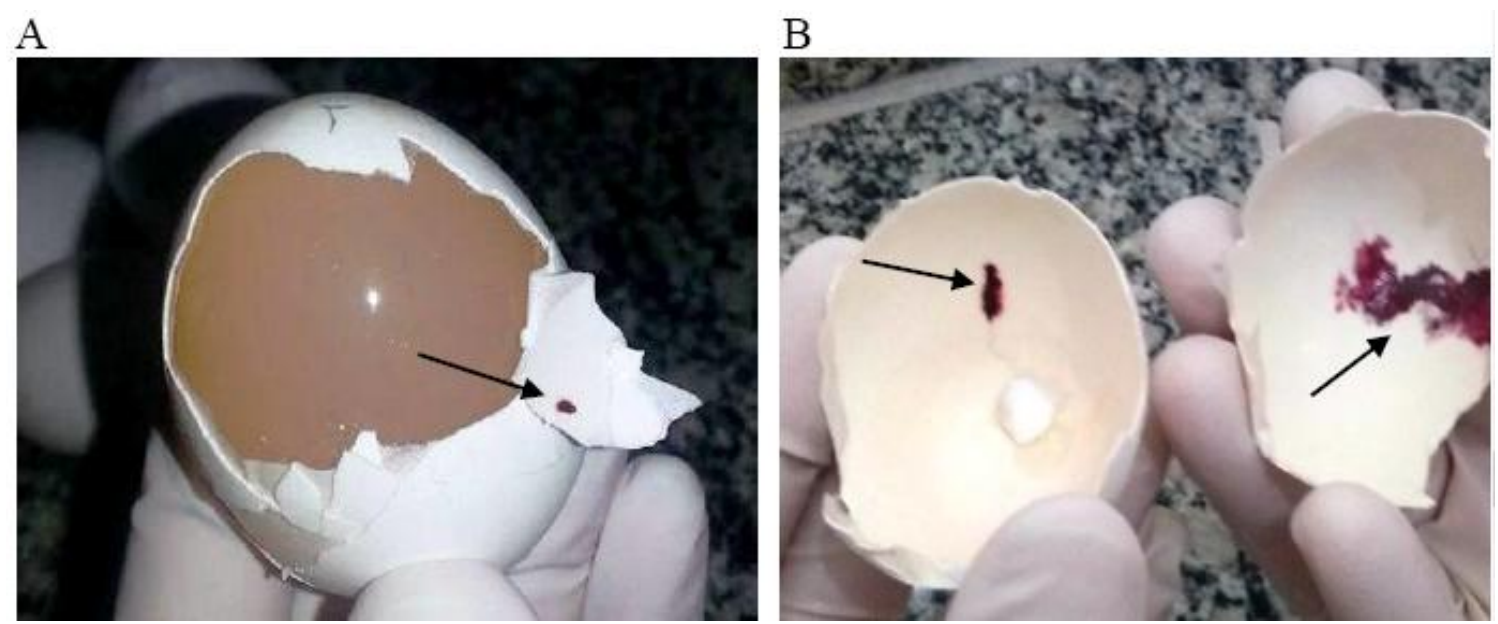

Figure 1. Presence of bacteria in the medial portion of the shell (arrows), first collection. A - 21 weeks; B - 39 weeks.
For the evaluation of bacterial penetration through eggshell, the inoculum used was a pool of bacterial samples in the concentration of $4.4 \times 10^{5} \mathrm{CFU} / \mathrm{mL}$

There was bacterial presence in the inner part of the shell (membrane) in all groups, as shown in Figure 1. 
In the first day after the immersion of the eggs, visualization of bacterial colonies in the agar of the studied groups was not possible, but after incubating them in agar from inside the eggs of all experimental groups, separately, bacterial colonies grew. Nevertheless, there was bacterial presence in the inner part of the shell (membrane) in all groups, as shown in Figure 1.

The only strains not isolated from the eggs of any evaluated group were Citrobacter freudii and Providencia stuartii. Overall, the first bacteria to reach the inside of the eggs were Pseudomonas aeruginosa and Serratia marcensces.

Regardless of age, bacterial samples with higher percentage of eggshell penetration throughout the 21-day timeframe were: Pseudomonas aeruginosa, Serratia marcensces e Salmonella Enteritidis, responsible for 100, 41 and $28 \%$ of penetration, respectively.

It is necessary to emphasize the importance of these bacteria both for public health and for the quality of the eggs of consumption. Bacteria such as Pseudomonas aeruginosa and Serratia marcensces, although considered opportunistic pathogens, can cause toxinfection when present in high concentrations. Because they are proteolytic, they produce substances such as acid and hydrogen sulfide, amines and ammonia, and oxidize fatty acids. They present a high potential of egg deterioration with consequent impairment of the sensorial and physico-chemical characteristics that alter the coloration, the aspect of the internal structures and the odor, which becomes putrid (Mendes et al., 2014).

Salmonella Enteritidis is the causative agent of foodborne outbreaks in humans most frequently associated with consumption of poultry products. It represents an imminent risk to public health mainly for children, elderly and immunosuppressed, because of the possibility of these outbreaks in these categories evolve to death (Shinohara et al., 2008).

Regardless of bacterial sample and the evaluated group, the visualization of colonies in the agar was more frequent after the fourth day of egg contamination. The CTT employed assisted in the identification of these colonies in the agar, tinting the bacterial colonies red (Figure $2-\mathrm{A}, \mathrm{B}$ and C). However, in a previous analysis (pilot), the visualization of these colonies in the agar was also possible without this resource (Figure 2D).

At the ages 21, 39, 51, and 62 weeks, averages of penetration percentage for all bacteria evaluated were 22, 23, 21 and 19\%, respectively. This data disagrees with findings by Reu et al. (2006), who observed a higher bacterial penetration of the eggs as the bird aged.

ST did not influence the penetration of the bacterial samples in the evaluated ages. This data agrees with findings by Smeltzer (1979) and Reu et al. (2006).

Detection in days and percentage of contamination of the groups by the bacterial samples studied are shown respectively in figure 3 and 4, with the exception of the Citrobacter freudii and Providencia stuartii strains, which showed no penetration capacity for the four ages in the evaluated period.

No correlation between pore size and bacterial penetration was found, even in the presence on bacteria inside the pores (Figure 5). This data corroborates findings by Reu et al. (2006). This can be due lack of significant difference $(\mathrm{P}>0.05)$ in age for this characteristic in this study. Possibly, some factor unrelated to shell porosity may have influenced the eggs resistance to bacterial penetration, such as shell membranes, for instance. 
Age influence on quality...

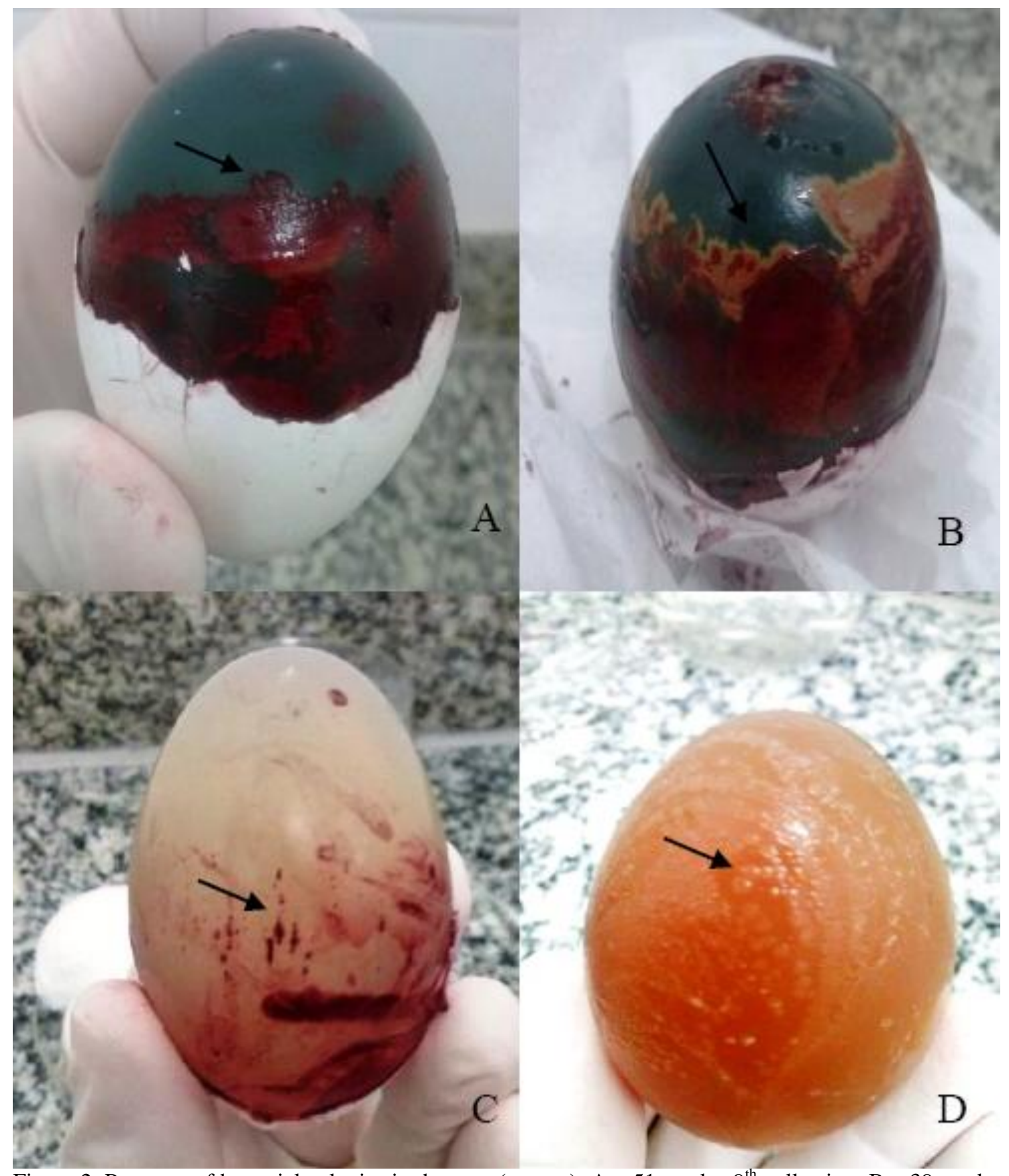

Figure 2. Presence of bacterial colonies in the agar (arrows). A -51 weeks, $9^{\text {th }}$ collection; B -39 weeks, $13^{\text {th }}$ collection; $\mathrm{C}-21$ weeks, $4^{\text {th }}$ collection; D - Colonies without CTT (pilot). 


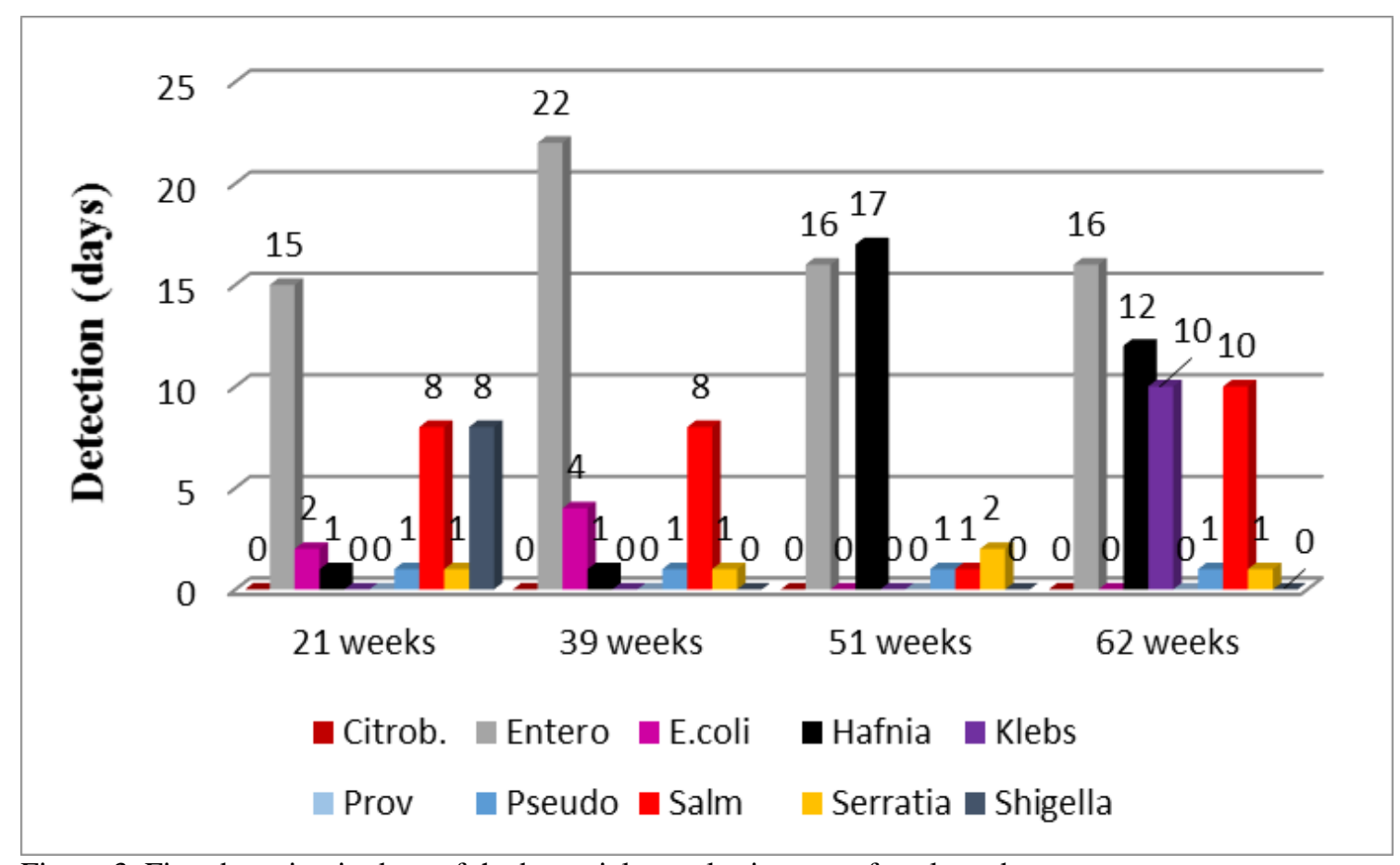

Figure 3. First detection in days of the bacterial samples in eggs of evaluated groups.

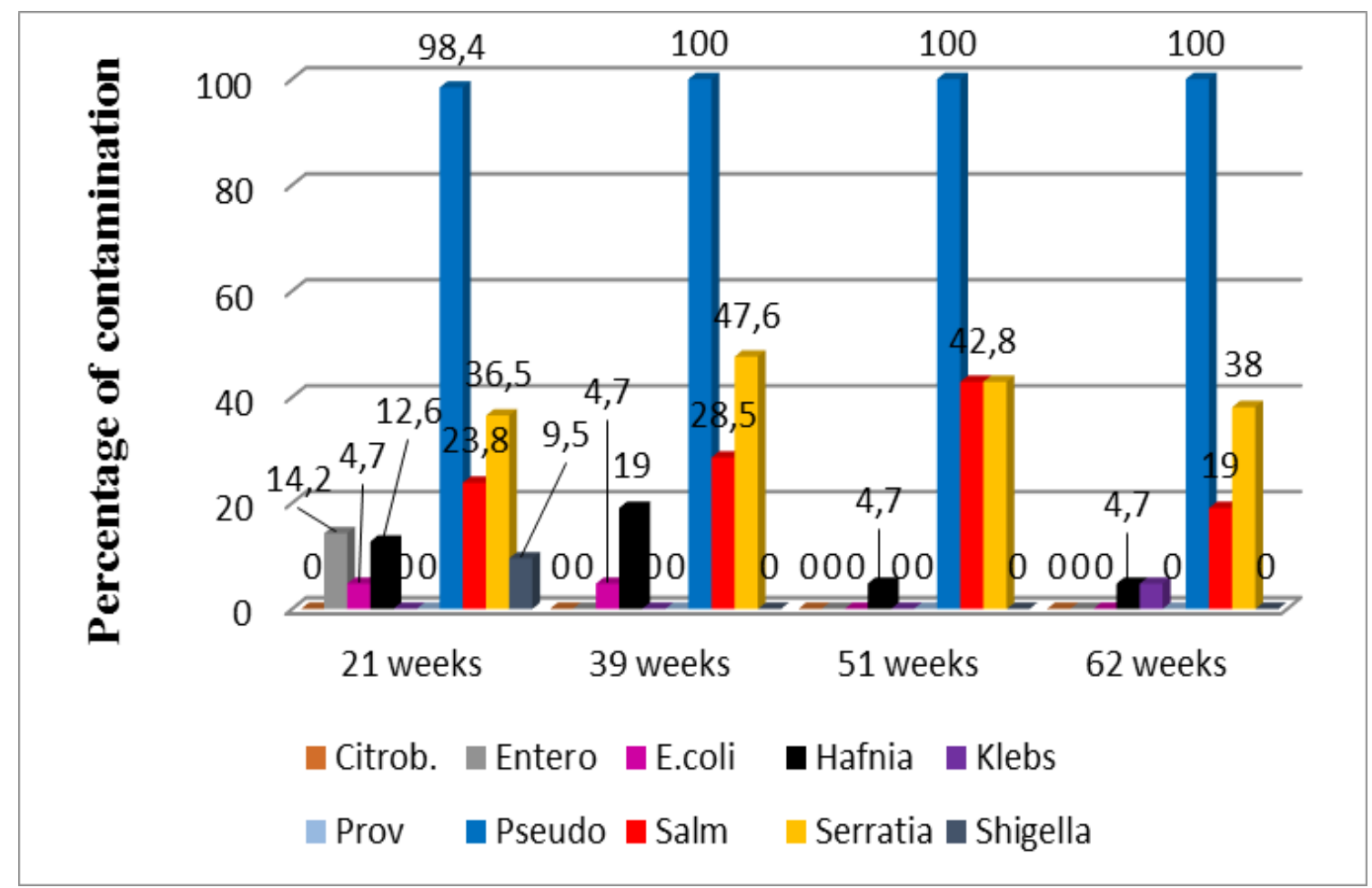

Figure 4. Percentage of egg contamination by the bacterial samples for the ages studied. 


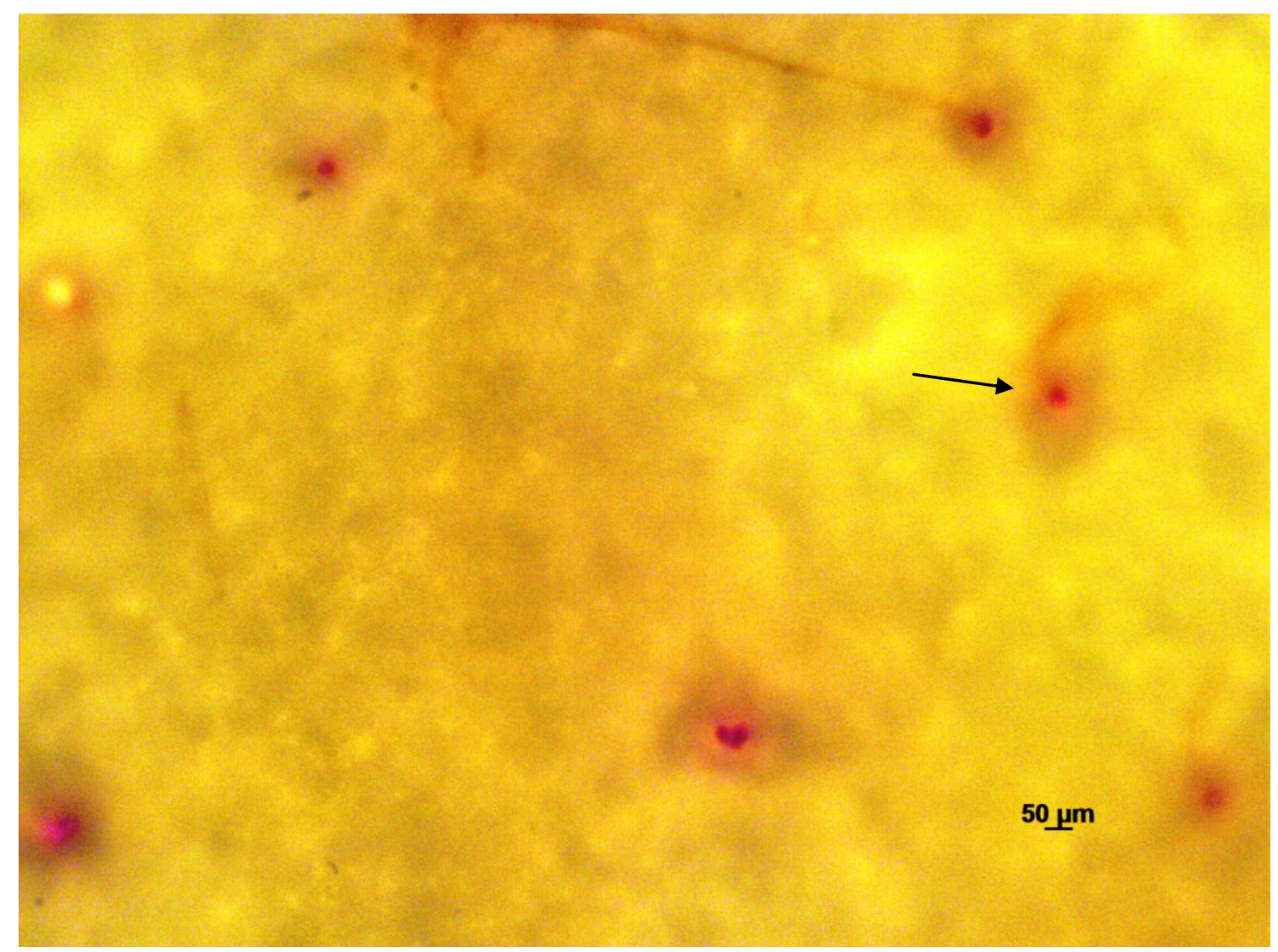

Figure 5. Shell fragment from the apical region of the group at the age of 51 weeks, showing the presence of bacteria stained with CTT inside the pores (arrows). $5 \mathrm{X}$ increase.

\section{CONCLUSION}

The method of filling eggs of laying hens in the first laying cycle with nutrient agar made possible the evaluation of bacterial penetration during the evaluated period, with direct influence of age in the penetration of bacterial samples with regard to shell quality.

\section{REFERENCES}

ALMEIDA, J.G.; DAHLKE, F.; MAIORKA, A. et al. Efeito da idade da matriz no tempo de eclosão, tempo de permanência do neonato no nascedouro e o peso do pintainho. Arch. Vet. Sci., v.11, p.45-49, 2006.

BARBOSA, V.M.; BAIÃO, N.C.; MENDES, P.M.M. et al. Avaliação da qualidade da casca de ovos provenientes de matrizes pesadas com diferentes idades. Arq. Bras. Med. Vet. Zootec., v.64, p.1036-1044, 2012.
CARVALHO, L.S.S.; FERNANDES, E.A. Formação e qualidade da casca de ovos de reprodutoras e poedeiras comerciais. Med. Vet., v.7, p.35-44, 2013.

COWAN, S.T. Gram-negative facultatively anaerobic rods. In: BUCHANAN; R.E.; GIBBONS, N.E. Bergey's manual of determinative bacteriology. Baltimore: Waverly Press, 1974. cap.8, p.290-332.

EDUCATION Analytical Software, version 9.4. Cary: SAS Institute, 2013.

HAMILTON, R.M.G. Methods and factors that affect measurement of egg shell quality. Poult. Sci., v.61, p.2022-2039, 1982.

KATAYAMA, E.R.; DONATO, T.C.; VERCESE, F. et al. Detecção de Salmonella enteritidis em ovos de codornas japonesas (Coturnix coturnix japonica - Temminck e Schlegel, 1849) submetidas a estresse cíclico pelo calor. Vet. Zootec., v.19, p.373-380, 2012. 
LAUVERS, G.; FERREIRA, V.P.A. Fatores que afetam a qualidade de pintos de um dia, desde a incubação até recebimento na granja. Rev. Cient. Eletron. Med. Vet., n.16, p.1-16, 2011.

MAZZUCO, H.; BERTECHINI, A.G. Critical points on egg production: causes, importance and incidence of eggshell breakage and defects. Ciênc. Agrotec., v.38, p.7-14, 2014.

MENDES, F.R.; LEANDRO, N.S.M.; ANDRADE, M.A. et al. Qualidade bacteriológica de ovos contaminados com Pseudomonas aeruginosa e armazenados em temperatura ambiente ou refrigerados. Cienc. Anim. Bras., v.15, p.444-450, 2014.

PINTO, A.T.; SILVA, E.N. Ensaios de penetração de Salmonella Enteritidis em ovos de galinha com diferentes qualidades de casca, submetidos ou não a lavagem industrial e a duas temperaturas de armazenagem. Arq. Bras. Med. Vet. Zootec., v.61, p.1196-1202, 2009.

RAGHIANTE, F.; ROCHA, T.S.; ROSSI, D.A. et al. Penetration time of Salmonella Heidelberg through shells of white and brown commercial eggs. Braz. J. Poult. Sci., v.12, p.273-277, 2010.

REU, K.; GRIJSPEERDT, K.; MESSENS, W. et al. Eggshell factors influencing eggshell penetration and whole egg contamination by different bacteria, including Salmonella enteritidis. Int. J. Food Microbiol., v.112, p.253260, 2006.

SAUTER, E.A.; PETERSEN, C.F. The effect of egg shell quality on penetration by various salmonellae. Poult. Sci., v.53, p.2159-2162, 1974.

SCALA JR., N. Aspectos físicos da incubação. In: GONZALES, E.; MACARI, M. Manual da Incubação 2.ed. Campinas: FACTA, 2003. p.97-124.
SHINOHARA, N.K.S.; BARROS, V.B.; JIMENEZ, S.M.C. et al. Salmonella spp., importante agente patogênico veiculado em alimentos. Ciênc. Saúde Colet., v.13, p.16751683, 2008.

SMELTZER, T.I. Bacterial penetration in floor and nest box eggs from meat and layer birds. Aust. Vet. J., v.55, p.592-593, 1979.

SOUZA, Y.L.S. Utilização da alga Lithothamnium calcareum para poedeiras de linhagens leves. 2012. 60f. Tese (Mestrado em Ciências Veterinárias) - Faculdade de Medicina Veterinária, Universidade Federal de Uberlândia, Uberlândia, MG.

SWIATKIEWICZ, S.; ARCZEWSKAWLOSEK, A.; KRAWCZYK, J. et al. Effects on performance and eggshell quality of particle size of calcium sources in laying hens' diets with different Ca concentrations. Arch. Anim. Breed., v.58, p.301-307, 2015.

TRINDADE, J.L.; NASCIMENTO, J.W.B.; FURTADO, D.A. Qualidade do ovo de galinhas poedeiras criadas em galpões no semi-árido paraibano. Rev. Bras. Eng. Agric. Ambient., v.11, p.652-657, 2007.

TYLER, C. Studies on egg shells. II. a method for marking and counting pores. J. Sci. Food Agric., n.4, p.266-272, 1953.

VALENTE, A.A. Qualidade da casca de ovos brancos e marrons obtidos no comércio da cidade de Jataí - GO. 2011. 21f. Dissertação (Bacharel em Zootecnia) - Curso de Zootecnia, Universidade Federal de Goiás, GO.

XAVIER, I.M.C.; CANÇADO, S.V.; FIGUEIREDO, T.C. et al. Qualidade de ovos de consumo submetidos a diferentes condições de armazenamento. Arq. Bras. Med. Vet. Zootec., v.60, p.953-959, 2008. 